\title{
Reviewing volcano hazard and risk communications in Ecuador: experiences from a fast-format workshop
}

\author{
Juan Anzieta ${ }^{\star \alpha, \beta}$, Glyn Williams-Jones ${ }^{\alpha}$, Benjamin Bernard $\gamma$, \\ Hugo D. Ortiz ${ }^{\beta, \delta}$, Silvia Vallejo $\gamma$, Mario Ruiz $\gamma$ \\ ${ }^{\alpha}$ Centre for Natural Hazards Research, Department of Earth Sciences, Simon Fraser University, \\ Burnaby, British Columbia, V5A 1S6, Canada.

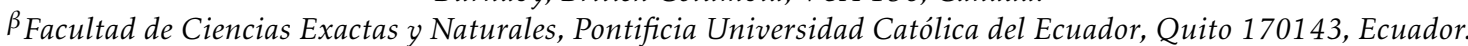

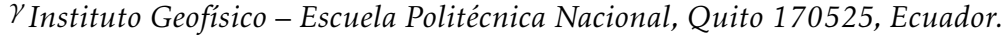 \\ ${ }^{\delta}$ Department of Earth Science and Earth Research Institute, University of California Santa Barbara, California 93106, USA.
}

\begin{abstract}
Hazard and risk communication requires the design and dissemination of clear messages that enhance people's actions before, during, and after volcanic crises. To create effective messages, the communication components such as message format and content, must be considered. Changes in technology are changing the way people communicate at an ever-increasing pace; thus, we propose revising the basic components of the communication process to improve the dialogue between scientists and the public. We describe communication issues during and outside volcanic crises in Ecuador and assess possible causes and consequences. These ideas were discussed during the short-duration "Volcano Geophysical Principles and Hazards Communications" Workshop in Baños, Ecuador in 2019. We review and propose communication strategies for volcanic hazards and risks that resulted from the workshop discussions and experiences of experts from the Instituto Geofísico (IG-EPN), local and international professors involved in volcano research and communication, and students from universities across Ecuador.
\end{abstract}

\begin{abstract}
La comunicación de peligros y riesgos requiere el diseño y difusión de mensajes claros que mejoren las acciones de las personas antes, durante y después de crisis volcánicas. Para crear mensajes efectivos, los componentes de comunicación como formato y contenido deben ser considerados. Cada vez más, la tecnología cambia la forma en que las personas se comunican, entonces proponemos revisar los principios del proceso de comunicación para mejorar el diálogo entre científicos y público. Describimos problemas de comunicación durante y fuera de crisis volcánicas en Ecuador y analizamos posibles causas y consecuencias. Las ideas se discutieron en el Taller de Comunicación de Peligros y Principios Geofísicos Volcánicos 2019 en Baños, Ecuador. Revisamos y proponemos estrategias de comunicación sobre peligros y riesgos volcánicos producto de discusiones y experiencias de expertos del Instituto Geofísico (IG-EPN), profesores locales e internacionales involucrados en investigación y comunicación de volcanes, $\mathrm{y}$ estudiantes de universidades del Ecuador.
\end{abstract}

Keywords: hazard communication; volcanic crises; communication processes; citizen engagement; multidisciplinary workshops; Ecuadorian volcanoes

\section{Introduction}

One of the primary goals of volcano hazard and risk communication is to provide people with adequate information to improve their ability to recognize and respond to the threat of volcanic hazards, as well as to understand the current state of volcanic activity, the current monitoring status, and projections for the near future. While this goal seems straightforward, difficulties often arise during the communication process. For instance, people take different actions depending on their understanding of the content, style, format, and delivery of messages, and their personal experiences [Paton et al. 2008]. The way information is dissemi-

${ }^{*}$ Corresponding author: janzieta@sfu.ca nated is constantly changing, either because of technological advances or because of evolving local or global circumstances that require rethinking and replacement of old paradigms. Nevertheless, fundamental principles of communication remain, and therefore, adapting to change is a matter of reviewing those concepts and combining past and current experiences with available and potential future tools. In this paper, we describe the results of a 3-day workshop focused on communications challenges faced in Ecuador, along with discussion and proposed strategies to improve and complement traditional communication methods [Ortiz 2018].

The "Volcano Geophysical Principles and Hazard Communication Workshop" was held in Baños, Ecuador (25-27 June, 2019) to share knowledge of geo- 
physical and geological principles, discuss communication experiences, and visit key field sites. Following guidelines described in the "Volcano Observatory Best Practices 2: Communication of Volcanic Hazards" [Pallister et al. 2019], the workshop aim was to better understand the difficulties in the communication process between the general public and academic and volcano observatory scientists [Paton et al. 2001; McGuire et al. 2009], as well as to investigate solutions to relevant scenarios that may occur during crises [Mei et al. 2013; Hicks and Few 2015]. An important part of this workshop was discussion of the various impacts on the people living near Tungurahua volcano and other volcanoes in Ecuador and abroad. Researchers from five national and international universities, the local monitoring agency (Instituto Geofísico de la Escuela Politécnica Nacional-IG-EPN), and undergraduate students of various academic disciplines from seven universities across Ecuador came together to discuss local and international experiences and different perceptions of risks and hazards. Other workshop activities ranged from visits to local volcanic deposits and monitoring sites, to lectures on the country's geodynamic context, in order to contextualize the local hazard and risk communication issues.

\subsection{Geological context of Ecuador}

Ecuador has diverse volcanic activity, from the continental subduction volcanism of the Andes to the hotspot volcanism in the Galápagos islands. Galápagos volcanoes are basaltic, resulting from the interaction of the Galápagos hotspot with the Galápagos Spreading Centre and give rise to the islands with frequent effusive volcanism [Geist et al. 1986]. In contrast, the widespread, mostly andesitic, continental volcanism is generally explosive and results from the convergence of the Nazca and South American plates and the formation of the Northern Volcanic Zone of the Andean Volcanic Arc [Stern 2004; Hall and Mothes 2008]. The Ecuadorian Andes span a $650 \mathrm{~km}$-long, $150 \mathrm{~km}$-wide segment of the Andes Cordillera. In northern Ecuador, two mountain chains with parallel NNE-SSE strike are separated by the Inter-Andean Valley [Stern 2004; Hall and Mothes 2008; Inguaggiato et al. 2010; Bablon et al. 2020]. Of the 77 Quaternary volcanic centres identified within the Ecuadorian Andes, at least 20 have been active in the Holocene and eight have been active since 1533 [Santamaria 2017]. The most recent notable activity began with the eruptions of Tungurahua and Guagua Pichincha in September and October 1999, respectively, and since then three additional volcanoes (El Reventador, Cotopaxi, Sangay) have erupted in continental Ecuador [Hall and Mothes 2008; Robin et al. 2008; Hidalgo et al. 2018; Almeida et al. 2019; Ortiz et al. 2020; Valverde et al. 2021]. These volcanoes showed different eruptive styles and eruption durations and led to different impacts on the population: Guagua Pichin- cha's eruption mainly resulted in ashfall on the capital city of Quito and the consequences (especially on the younger population) lasted for a few months [Naumova et al. 2007]; Tungurahua's eruption lasted 16 years with explosions that occasionally caused significant ash emissions and pyroclastic density currents (PDC) that impacted local communities in various forms [Few et al. 2017]; El Reventador and Sangay volcanoes continue to erupt almost without interruption to this day, with outbursts of explosions and small to medium PDCs and a relatively rapid landscape change [Ortiz et al. 2021; Valverde et al. 2021]; Cotopaxi volcano's brief reactivation in 2015 lasted for a few months with a paroxysm with a volcano explosivity index (VEI) of 2 and a lowlevel ash plume that caused social distress in nearby $(\sim 14 \mathrm{~km})$ communities [Hidalgo et al. 2018; GomezZapata et al. 2021]. The high spatial density of active Holocene volcanoes and associated volcanic hazards has impacted pre-Columbian populations [Isaacson and Zeidler 1999; Hall and Mothes 2008; Vallego Vargas 2011; Le Pennec 2013] and continues to impact contemporary populations [Le Pennec et al. 2008; Biass et al. 2012; Le Pennec et al. 2012] in the region. Population growth, particularly in the large urban centres of the Inter-Andean Valley [Villacís et al. 2011], is increasing exposure to volcanic hazards and thus there is a need for more effective and continuously evolving hazard and risk communication, especially with vulnerable communities.

\section{THE COMMUNICATION PROCESS}

In general, while many variations exist on the communication process, one of the most basic models involves four components: 1) emitter or source, 2) message or information, 3) medium or channel, and 4) receptor or receiver of the information [Berlo 1960]. While this model has been modified and expanded to include the many aspects of communications (e.g. the existence of noise in the message, feedback and actions taken after communication), the scheme is valid for many types of communication processes. In human communication the final interpretation is key because the response is directly related to the understanding of the message. Communication processes can be imperfect, and its components can suffer from complications such as coding/decoding of the message, noise, multiple competing sources, etc. [e.g. Stephens et al. 2013].

The message, and most importantly, actions derived from the interpretation are crucial in hazard and risk communication. In this work we focus on the effectiveness of communication with the public [e.g. McGuire et al. 2009] rather than the "contextualization" problem involving the interface between volcanologists and risk governance decision makers [Bretton et al. 2018a]. In an ideal scenario to communicate efficiently, we need to understand and identify people's needs and their 
current knowledge and mental models (e.g. concepts, awareness, and causal connections of possible events) of volcanic risks [Cardona 2004]. One approach requires surveying a statistically significant sample of each of the subpopulations within a region to assess their current knowledge, however, this is often logistically challenging. For instance, surveys can take many months [Few et al. 2017] and require a large number of surveyed subjects who sometimes only partially complete the poll, do not collaborate at all [Paton et al. 2001], or are hard to reach [Christie et al. 2015]. Moreover, the topics and elements of surveys must be chosen carefully [Paton et al. 2001] and in-depth studies may seek to incorporate past cultural experiences or traditions of the population [Cashman and Cronin 2008] to capture potential useful information on risk perception.

We look to improve communications by examining only components 1 and 3 of the current hazard and risk communication process: the source and the channel. This involves revising and rethinking aspects on the format and terminology of the message rather than issues in the content of the message [McGuire et al. 2009]. Thus, we study a few instances of the current state of the message reception and the efficacy of different communication channels for different audiences within the population, by reviewing past and current experiences of volcanic hazards communicators in Ecuador and around the world. As a starting point, we examine and identify problems that appear during the communication between official sources and potentially vulnerable people in the local context (Figure 1) and provide some relevant examples of similar situations abroad. We emphasize that we do not study scenarios where members of the population can become "sources" of information as they can create messages and narratives based on their own perceptions and ideas, or scenarios where members become channels (messengers) for messages at any point during a volcanic hazard since those cases are beyond the capabilities of the official entities. Additionally, we acknowledge that not all newsletters produce false or inaccurate information, and most share verified information. However, we focus on cases of newsletters or other media acting as sources of flawed information that go beyond their primary role as channels of communication (see Section 2.2).

Figure 1 shows a simplified scheme of the communication process in Ecuador. The official source of information related to volcanic hazards is IG-EPN, it produces daily bulletins on the status of active volcanoes, issues automatic alerts for significant earthquakes or unusual events, and generates reports of changes in volcanic activity to communicate with the media, other governmental entities, and subsequently the public. Since natural hazards are perceived by different actors in the population at different moments, and each can have their own interpretations or intentions, the dissemination of inaccurate information and other prob-

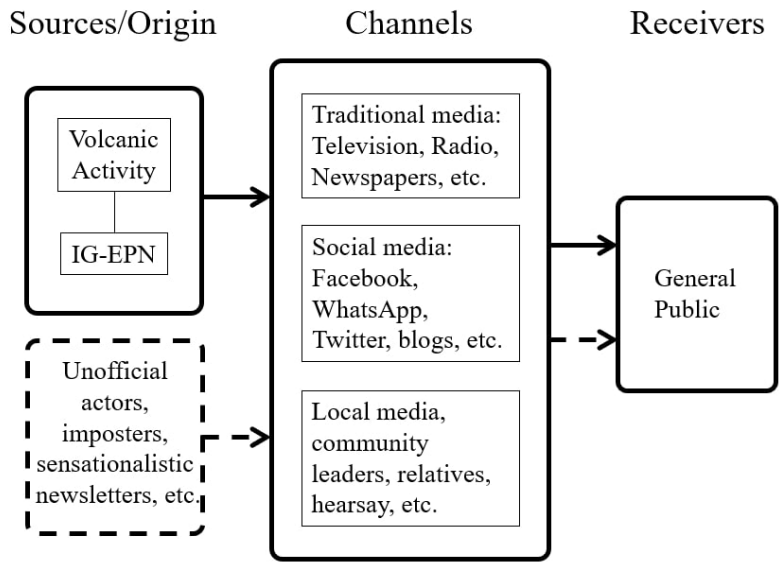

Figure 1: Simplified summary of the communication process during a volcanic hazard in Ecuador. The dashed lines indicate the potential for inaccurate information dissemination.

lems can occur (dashed arrows in Figure 1) during the communication process.

\subsection{Problems associated with the message source}

The source (origin) of the information has two elements: the hazards and producers of information about the hazards. We summarize different aspects of each element and common misinterpretations that may result in problems in the collective imagination and disturb communications. Below we identify and discuss a few issues using local examples and experiences along with some similar occurrences abroad.

\subsubsection{The hazard as a source}

As hazards occur, the features and activity of volcanoes become sources of information: people experiencing volcanic hazards or other changes in volcanic activity process the information and make decisions based on their interpretation of those observations. Since volcanoes can behave in various ways that may imply different hazards, they require different responses from the population. Consequently, people need to be able to appropriately interpret all information related to the threats from volcanoes (directly from the natural hazard or from other sources).

Several aspects that can impact effective hazard communication locally (and internationally) were identified and discussed at the workshop:

1. Volcanoes can have different eruptive styles and impacts, and these could be unknown to the general public. For example, some groups think that Cotopaxi volcano is dangerous because of possible lava flows [Christie et al. 2015], while the greater danger during an eruption comes from the po- 
tentially devastating primary lahars or mudflows [Mothes et al. 2004]. People in the vicinity of Cotopaxi even consider the occurrence of lahars to be impossible within their lifetimes while still acknowledging the volcano as the major local hazard [Gomez-Zapata et al. 2021]. Others are unaware that the volcanoes in the Galapagos pose little hazard to the population as they have mostly effusive eruptions with lava flows that extend for a few kilometres from the volcanoes [Naumann and Geist 2000].

2. Misconceptions of the status of volcanic activity people consider a volcano to be active based on superficial signs of activity (e.g. degassing) but are unaware of the subsurface volcanic processes, timescales (weeks to years), and uncertainties associated with geophysical processes leading to eruptions. For example, near Cotopaxi, many residents believe they can evaluate the activity and threat of the volcano through regular visual observations [Christie et al. 2015], and in general, either locally or abroad, the assessment of volcano activity differs substantially between the general public and scientists [Haynes et al. 2008; Bachri et al. 2015].

3. Terminology, conventions, and derived interpretations [McGuire et al. 2009] - some people do not fully understand the differences between pyroclastic flows, lava flows or lahars; often these terms are grouped in one category, leading to inadequate actions [Martí 2015].

4. Hazard map literacy and specificity [Thompson et al. 2015; Marti et al. 2019] - people can become overwhelmed by hazard maps, and they usually require specific design considerations such as colour-blind sensitive palettes, or cultural conventions [Thompson et al. 2015]. People may be unable to read a map and locate their surroundings, interpret symbols, landmarks, or topographic features such as contour lines. Near Cotopaxi volcano for example, only about half of the respondents of a recent survey know if they live in a hazard zone [Gomez-Zapata et al. 2021].

5. Permanence of knowledge - although people might learn about volcanoes during specific events, as time passes, the acquired knowledge tends to fade; this phenomenon has happened locally as well as abroad [Mothes et al. 2015; Syahbana et al. 2019]. Additionally, lived experiences do not necessarily translate to a more prepared state [Paton et al. 2008].

The origin of these problems is in part derived from popular knowledge about volcanoes. Academic or technical references are not readily accessible to the general public in Ecuador, and most information they receive comes from the media, which itself typically lacks basic knowledge of Earth sciences. There is no school curriculum for local volcanology and thus volcanic hazards are often misunderstood, and potentially inaccurate or misleading information can spread through rumourbased intra-community tales. This is a major problem because as people age, they become less likely to learn or remember topics outside of their work settings or personal interests [Howard and Howard 2013]. In addition, volcanic processes are complex, and the details cannot easily be learned in a short time to have a lasting impact. It is thus important to understand how each community receives information and to find ways to summarize and effectively deliver that information with the goal of teaching proper actions before, during and after volcanic crises.

\subsubsection{The message producer as a source}

Another issue related to the source or origin of information is the lack of public knowledge about the scientific and technical entities that are officially responsible for monitoring, investigation, and reporting on the nature, timing, and likelihood of volcanic activity. In Ecuador, the IG-EPN is responsible for the monitoring and firsthand communication of most geophysical processes (including volcanic eruptions) while the civil response, warnings, and evacuation protocols are the responsibility of the Servicio Nacional de Gestión de Riesgos y Emergencias (SNGRE, formerly Secretaría de Gestión de Riesgos). Researchers and monitoring personnel at these national agencies create the official information-the message-which has different complexity levels and scopes that can be misunderstood by the public (e.g. difficulties in identifying between an instantaneous report, a follow up, an update or correction, or an evaluation report of the activity of a volcano). However, while volcanologists and other scientists are increasingly becoming legally required to communicate precisely and clearly, especially after events in l'Aquila, Italy [Benessia and De Marchi 2017], in the end it is the people who identify the sources, decode the messages, internalize the information, and make informed decisions. Thus, effective communication requires proper source identification and expectations. Problems that undermine this communication can come from: 1) A general lack of knowledge about which official agencies are responsible for hazard and risk communications and what their roles and responsibilities include. Members of the general public often confuse names and responsibilities of the entities, demanding information or actions from the wrong entity. For example, some think that the Instituto Geográfico Militar (IGM) is the same institution as the IG-EPN, but the IGM has the goal of developing geographic information products mostly unrelated to geophysical hazards. 2) Confusion about where to find official information. For example, different groups think that channels (see Section 2.2) such as social networks 
and online published articles are the actual sources (origin) of official information, thus sometimes people read, believe and/or take action based on inaccurate or false information (e.g. people wrongly believe in claims of eruption predictions), which can rapidly spread or become "viral" on social networks [Vosoughi et al. 2018]. 3) Unofficial sources of information with potentially inaccurate content can include individuals with saviour complex, imposters, politicians, etc. There have even been cases of fake institutional webpages or misinformed public figures in social networks leading to unnecessary panic or actions in the population; this has been observed in other countries [Newhall et al. 1999; Sennert et al. 2015; Krippner 2018; Rubin 2018] and can complicate the response to crises [Syahbana et al. 2019]. Within unofficial platforms such as social networks or articles of varying levels of rigour, individuals or groups seeking self-promotion or recognition have made inaccurate statements (e.g. by making claims of the ability to predict earthquakes that have been later disproven [Yepes et al. 2020]); or that have issued inopportune critiques that have harmed the perception of the primary information source. This can lead to 4) lack of trust in official sources and authorities by certain communities or groups [Lane et al. 2003; Mothes et al. 2015]. The lack of trust may be towards the institutions or specific individuals that represent them [Haynes et al. 2007] and can result in poor decisions or interpretations made by the population. This confusion or uncertainty can further create friction between the population and the volcano observatories [Mothes et al. 2015] and may lead to (potentially harsh) criticism or disagreement with the content of the messages. Scientists can feel undermined when their message does not reach the population in the planned way further undermining communication overall, therefore positive reinforcement could be needed to mitigate the scientists' possible "impostorism" or self-doubt [Vergauwe et al. 2014; Gardner et al. 2019]. An example of mistrust towards IG-EPN occurs regarding the automatic reports of earthquake information issued when a preset magnitude threshold is surpassed: People mistrust this procedure when an earthquake is felt locally but it is not large enough to be reported. In a similar fashion, some people are confused and suspicious when the local earthquake magnitude reports differ from international reports such as those provided by the USGS; people often express their concerns in social media platforms. 5) Different scenarios for volcanic eruptions and other hazards are best expressed probabilistically by the scientists and official sources, yet the concept of "probability" is non-intuitive and not fully understood by the general public [Fischhoff 2013; Doyle et al. 2014; Martí 2015]. Inability to communicate or digest the probabilistic scenarios has caused people to ignore instructions when crises have occurred in Ecuador or abroad, either because they deem the situation less dangerous than it really is, or because they insist their per- sonal belongings, livelihood or lifestyle are more important than evacuation in case danger is "not imminent" [Tobin and Whiteford 2002; Haynes et al. 2008; Sharma and Patt 2011; Bowman and White 2012; Mei et al. 2013; Christie et al. 2015; Mothes et al. 2015; Armijos et al. 2017; Syahbana et al. 2019]. This fact also affects trust in the official sources whenever there are difficulties in clearly expressing the uncertainties of the different eruptive scenarios [Haynes et al. 2007; 2008].

\subsection{Problems associated with the message channels}

Message channels are any means through which information is delivered to receptors, with special attention to those who live in areas at risk. The channels range from traditional media such as television, newspapers, radio, to internet-based channels predominantly in the form of social media (e.g. Facebook, WhatsApp, Twitter); they may also include blogs and on-line bulletins, and those transmitted word-of-mouth. All channels are in principle open, therefore different sources (official or unofficial) can use them depending on the scope and reach. We recognize the following difficulties with the message channels around the world. 1) A lack of clear differentiation between source and channels. For instance, social media is increasing as a resource for news and information [Chen 2021], and the distinction between verified and unverified information is also becoming increasingly fuzzy. This can lead people to receive misleading and inaccurate information [Gupta et al. 2013] and possibly take inappropriate or dangerous actions [Krippner 2018; Syahbana et al. 2019]. 2) The various communication channels have restrictions in format and content length causing the original message to become abbreviated or modified, diminishing its efficacy (e.g. Twitter). 3) Local context, information accessibility [Jones et al. 2013] and speed can delay a timely delivery of information to the people. For many parts of Ecuador, including whole communities, traditional and social media are inaccessible due to the lack of Internet and cell phone coverage, which limits critical information dissemination and adequate communication of evacuation protocols. The consequences of insufficient accessibility to updated information were experienced during the Cotopaxi volcano crisis in 2015, which caused social chaos even with a low magnitude VEI 2 eruption [Gomez-Zapata et al. 2021]. Similar information accessibility problems are currently affecting the rural communities near Sangay volcano which continue to suffer the effects of the largest eruptive episode in $\sim 50$ years. The speed of the message is critical so that people can make informed decisions in time. However, the fastest channels of communication are usually social networks (social media) while also often being the least curated and controlled [Williams and Krippner 2019], thus fake information tends to spread faster [Vosoughi et al. 2018] and this leads to the next problem. 4) In general, channels still have lim- 
ited curation/arbitration of content. For instance, the press or other traditional media are somewhat more reliable than social media due to presumed verification of sources; however, it is often much slower and unidirectional compared to social media and there are numerous examples where official information was misrepresented in the press for political or economic gain, resulting in undue panic [Sennert et al. 2015; Krippner 2018; Rubin 2018; Williams and Krippner 2019]. A recent example was the release of news [e.g. Primicias 2020] that sparked some panic in Ecuador regarding the possible flank collapse of Tungurahua volcano. The public media (national and international) exaggerated-probably unintentionally-the title and conclusions from a scientific publication by Hickey et al. [2020], which stated as one of several possible scenarios that the west slope of Tungurahua could suffer a collapse. The press claimed that a collapse was imminent, causing confusion, unnecessary concern, and a subsequent scientific clarification by the IG-EPN [IGEPN 2020a]. Similarly, during the COVID-19 global pandemic crisis, due to increased exposure to news, people thought the occurrence of elevated activity at tens of volcanoes around the world was "anomalous" given widespread and inaccurate diffusion in social media and shocking web news [Nación 2020].

\section{WORKSHOP DESCRIPTION}

\subsection{Conception}

Some studies have collected personal experiences of scientists to understand the communication interface with risk management institutions and the public (e.g. in the form of a survey as in Bretton et al. [2018b], or in academic meetings as in Pallister et al. [2019]), while other studies focus on the understanding and perceptions of the public for which the message is intended [Paton et al. 2001; Bird 2009; Christie et al. 2015; Few et al. 2017]. Many approaches must be tried since creating an effective communication mechanism or style can be difficult due to the economic and cultural conditions of each region [Gaillard and Dibben 2008; Haynes et al. 2008; Jones et al. 2013], and involvement of a diverse population can result in better communication strategies and risk reduction in general [Haynes et al. 2020]. In Ecuador, many surveys have recorded the experiences and perceptions of inhabitants near volcanoes [e.g. Tobin and Whiteford 2002; Christie et al. 2015; Few et al. 2017; Czerny and Czerny 2020; Gomez-Zapata et al. 2021], to achieve higher participation of the communities for the crisis management and for tailoring custom messages to better reach the public. Furthermore, a balance in the amount of responsibility that is shared between agencies and public must also be considered to avoid normalization of vulnerability and individualization of responsibility, i.e. to appropriately define and distinguish resilience and autonomy of the people from abandonment from state agencies [Gladfelter 2018]. Consequently, we leveraged the relatively simple logistics and fast format (3 days) of the 2019 Volcano Geophysical Principles and Hazards Communications Workshop to quickly examine the current state of hazard and risk communications in Ecuador. Rather than surveying a large portion of the population, our focus was on revising the principles of the communication process while incorporating diverse inputs and perspectives; the workshop combined experiences from scientists who have expertise in both assessing and communicating hazard and risk, with the students' perspectives to identify knowledge gaps or preconceptions while learning how to more effectively communicate scientific knowledge.

\subsection{Participants}

Participants consisted of local and international university professors with varying experience in volcano monitoring and hazard communications and 19 undergraduate students from 7 universities from across Ecuador. The participants were invited to share experiences, knowledge, and perspectives on geophysical activity, hazards and risk communication to further advance the communication capabilities in Ecuador as part of a multi-institutional collaboration. Participant universities are located in Coastal, Andean, and Amazon regions and students represented various disciplines including geology, physics, risk management, and civil engineering. The institutions involved and number of participants from each are summarized in Table 1.

The format of the workshop included open discussions, in combination with lectures, to encourage active participation about the fundamental principles in the process of communication, ranging from the creation of a message to the means of delivering it. The workshop integrated participants with heterogeneous experiences (in terms of confronting and communicating volcanic hazards). Students from the Amazon and Coastal regions seldom interact with the effects of the active Andean volcanoes, students in risk management or geology are more familiar with hazards and risk communications than physics students, and the professors all hold positions with varying levels of involvement in academic research, monitoring, and hazard and risk communication.

\subsection{Activities}

Before opening the discussions about how to improve hazard communication in the Ecuadorian context, we reviewed scientific and social concepts in the venue and in the field. We consider that the concepts encompass important parts of the knowledge that must be contin- 
Table 1: Summary of institutions and workshop participants.

\begin{tabular}{|c|c|c|}
\hline Institution & Participants & Country/Region \\
\hline Pontificia Universidad Católica del Ecuador - PUCE & 2 professors -2 students & Ecuador (Andean Region) \\
\hline Instituto Geofísico - Escuela Politécnica Nacional / IG-EPN \& EPN & 3 professors ( 1 online) -6 students & Ecuador (Andean Region) \\
\hline Universidad Yachay-Tech - YACHAY & 2 professors -7 students & Ecuador (Andean Region) \\
\hline Boise State University - BSU & 1 professor & USA \\
\hline raser University - SFU & 1 professor (online) & Canada \\
\hline Universidad de las Fuerzas Armadas ESPE - ESPE & 1 student & Ecuador (Andean Region) \\
\hline Escuela Politécnica del Litoral - ESPOL & 1 student & Ecuador (Coastal Region) \\
\hline Universidad de la Amazonía - IKIAM & 1 student & Ecuador (Amazon Region) \\
\hline Universidad Estatal de Bolívar - UEB & 1 student & Ecuador (Andean Region) \\
\hline
\end{tabular}

uously considered and updated for effective communication, and we detail the activities around them below.

\subsubsection{Field observations}

We visited several field sites to help with the understanding of the geological and physical characteristics of volcanic hazards. This included a few field stops along the road between Quito and Baños to show students how to recognize volcanic deposits and their characteristics (e.g. origin, dynamics, material, transport mode, size, source distance, etc.; Figure 2A, B), and their past and potential impact on nearby communities. The main field sites were located on Tungurahua volcano, where we examined several outcrops exhibiting recent and past eruptive deposits. The aim was to emphasize the large spatial-temporal scales and magnitudes of volcanoes and their corresponding hazards. Another goal was to raise the awareness of the participants about the tightly spaced volcanoes forming the Ecuadorian Andes and their proximity to populated areas; all of which is crucial for relevant hazards communication.

\subsubsection{Perception and experiences of the public}

Knowing the perception and experiences of the public is valuable to understand how best to communicate the local volcanic hazard and risk. We listened to the experiences of a local "vigía" [watchmen; Mothes et al. 2015] living on the upper foothills of Tungurahua who operates his own volcano interpretation centre. This visit consisted of a short talk by the watchman, Carlos Sánchez, who recounted his personal experience of being a vigía for over 20 years, observing audio-visual material, and inspecting volcanic samples from the recent eruptions of Tungurahua volcano (Figure 3A, B). Mr. Sánchez helped the IG-EPN with local volcano monitoring and hazard mitigation when the volcano was erupting and continues to support IG-EPN along with other vigías to communicate anomalies in the region related to weather, anomalous sounds and odours, secondary lahars, etc. While his experience is only one of many from around the volcano, exchanging ideas personally leads to increased awareness of the people's different languages, perspectives, and needs.

\subsubsection{Lectures on scientific knowledge}

Another aspect we took into consideration for volcano risk and hazards communication is holistic knowledge of the geological, geophysical, and general scientific aspects of the volcanic hazards. The workshop instructors held various lectures about volcano monitoring advances in Ecuador. Lectures included a review of the work of the IG-EPN over more than 37 years, the history of volcanism in Ecuador including eruptive styles, geophysical instrumentation, monitoring principles (Figure 4), and hazard and risk communication elements. Additionally, we held two video conferences on the experiences of one local and one international volcano science communicator.

\subsubsection{Comprehensive discussions}

Extensive discussions reconciling the reviewed knowledge components with the problems associated with the sources and channels of communication described in Section 2 were held throughout the workshop. Discussions focused on the current state of hazard and risk communication in Ecuador but included examples of similar situations around the World. The discussions included personal experiences and views of lecturers and students so that all participants had an equal opportunity to express their ideas and knowledge. Dynamic debate on many concepts and perceptions offered a rich environment to assess different subtleties related to volcano science and public communication. While this is only one of the many ways that productive discussions can be held for the improvement of hazard and risk communication, the possible enhancements and solutions identified for some of the problems are novel, at least for the local context.

\section{Proposed communication Strategies}

Here we summarize some strategies implemented in Ecuador and other countries and discussed during the workshop. We also present new approaches that could be implemented to address some of the previously 


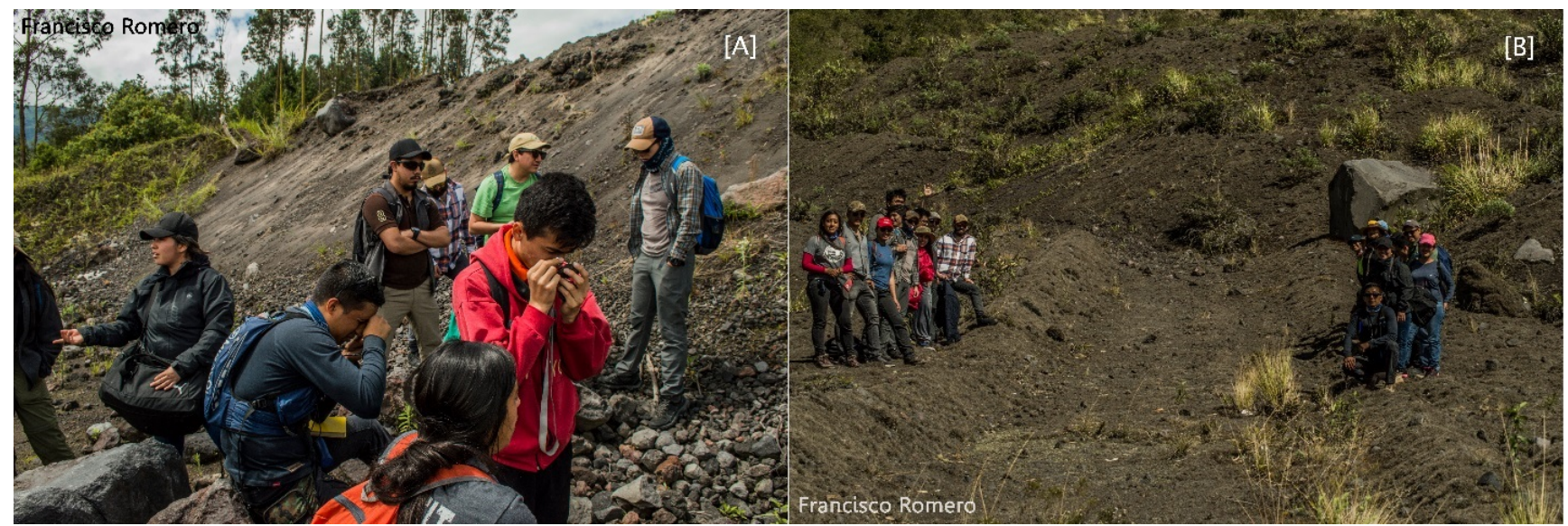

Figure 2: On the flanks of Tungurahua volcano, $[\mathrm{A}]$ students study deposits, and $[\mathrm{B}]$ pose near a levee from a pyroclastic density current deposit from the latest eruptive period.

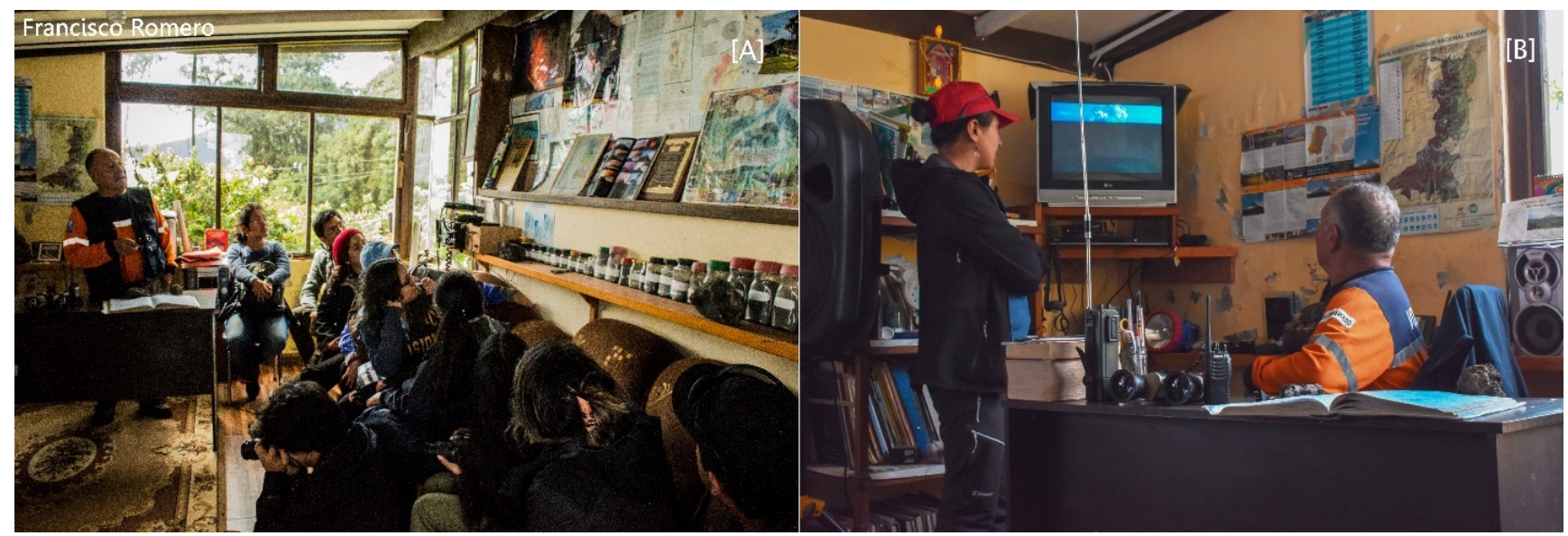

Figure 3: $[A]$ Carlos Sánchez, a local "vigía" at Tungurahua Volcano, shares his experiences and [B] participants review footage from Tungurahua's most recent activity.

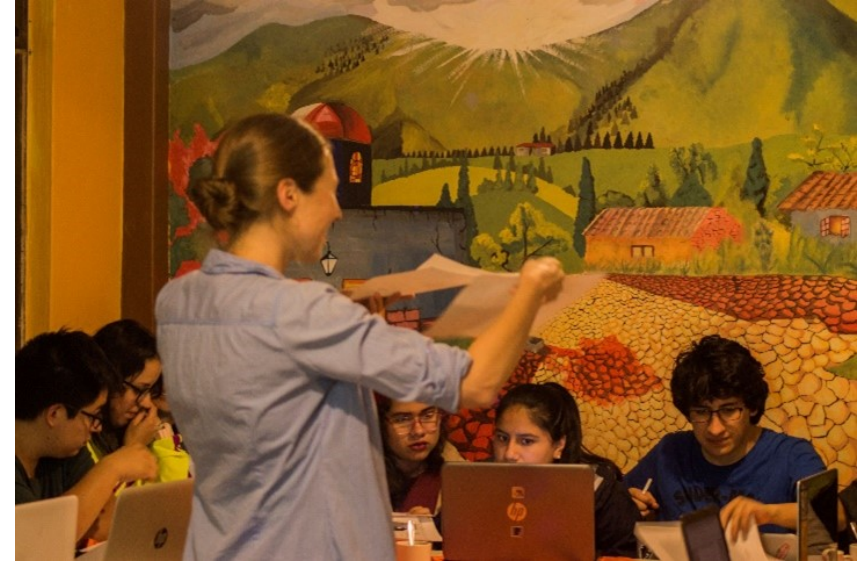

Figure 4: Professor Ana Foster from Universidad Yachay Tech, hands worksheets to students to review concepts on geophysical and monitoring principles. identified communication problems (see Section 2) and to improve hazard and risk communication. These approaches include personal interactions, technologybased communication, the creation and dissemination of hazard and impact map tools, scientific reports, and research results, and the use of sharing methods that are becoming standard practice such as social media [McGuire et al. 2009; Pallister et al. 2019; Haynes et al. 2020].

As discussed earlier, the lack of education about volcanic hazards is the main obstacle for people to adequately understand the information they receive and to respond in an informed manner during a crisis. An ideal solution is to promote national educational programs that include basic geology or volcano hazards in elementary school curricula. However, this pathway is unlikely as addition of education programs are unrealistic due to limited budgets or little political support for change. Therefore, we review two different mechanisms to further share knowledge with the public, 
by engaging the community in on-line and in-person forums [McGuire et al. 2009; Williams and Krippner 2019].

\subsection{Interpersonal communication strategies}

An effective strategy for community education is direct contact with the people [Pallister et al. 2019]. One activity currently performed by experts at IGEPN is to visit communities and present information on the nearby volcanic hazards (e.g. from Tungurahua, Cotopaxi, Chiles-Cerro Negro, El Reventador, Sangay volcanoes). They also organize free summer courses for youth to learn basic volcanology concepts as well as public meetings and scientific presentations at the IG-EPN headquarters. In addition, they run volcanology workshops where high school students play roles of people involved in a volcanic crisis (e.g. affected population, authorities, scientists, etc.) [IG-EPN 2020b]. However, these options require physical attendance, which can impact participation because of limited personnel, facilities capacity, and transportation to the class. Nevertheless, in-person activities can lead to better learning outcomes due to personalization and contextualization of the way the information is shared [Bernacki and Walkington 2018] and trustbuilding. Due to the necessity to self-isolate during the COVID-19 global pandemic, these courses are now implemented in a virtual format and offered to $\sim 300$ students (between 10 and 13 years old) and to elementary school teachers. Since personal engagement is twoway communication, it allows for information about the possible hazards to be better delivered to the people (i.e. doubts and terminology can be explained immediately), so informed decisions can be made towards evacuation or sheltering [Bird 2009; Thompson et al. 2015].

One of the most successful experiences in Ecuador is the joint work of the community with IG-EPN supported by the Observatorio del Volcán Tungurahua (OVT), the local volcano observatory [Mothes et al. 2015]. While Tungurahua volcano was in eruption, IGEPN along with foreign collaborators, provided training to inhabitants near the volcano. In addition, the Civil Defence and now Servicio Integrado de Seguridad ECU911 (ECU911) continue to supply the community with radios for rapid communication. The "vigías" report any observations of the volcano's state of activity (e.g. ashfall characteristics, unusual sulphur smells, possible presence of secondary lahars, heavy rains, etc.) to the IG-EPN seeking guidance if needed, thus leading to a more rapid and dedicated channel to exchange information with the local population. This solution encourages the community to engage in the volcano monitoring and the communication process, enhances trust in the institutions and information, and finally the official guidance provided during a crisis are likely to be followed [Stone et al. 2014; Mothes et al. 2015; Armi- jos et al. 2017; Few et al. 2017]. The Center for Volcanology and Geological Hazard Mitigation (CVGHM) in Indonesia applies a similar strategy. In Indonesia, communication requires the use of the many local dialects to be effective, and thus CVGHM created a network of in-situ observatories staffed by local community members [Andreastuti et al. 2017] with multiplex radio-based systems to issue instant warnings to community officials, and pass information on how to best respond during volcanic crises [Syahbana et al. 2019]. As another recent example in a developing country, a strategy related to earthquake risk reduction is currently being initiated in Haiti with the integration and exchange of information between scientists and local citizens. They do this through the installation of lowcost seismometers inside private homes and the creation of a web portal designed for the people to view earthquake locations on a map [Calais et al. 2020]. Citizen science initiatives such as this are becoming more and more prevalent with the use of emerging technologies and the incorporation of strategies from the social sciences that can prove useful not only to enhance hazard and risk communication, but for disaster risk reduction in general [Hicks et al. 2019].

A key strategy discussed during the workshop aimed at encouraging the local population to follow evacuation instructions during crises. We review a successful approach implemented during flooding and landslide events in Ecuador. Sometimes people may refuse to follow evacuation notices because of fear that their belongings will be stolen or that their livestock may die during the disaster. During 2017, in response to a river overflow event, the people of the Chimbo area in the province of Bolivar (Ecuador) had to be evacuated from a zone at high risk of landslides. Community members only agreed to evacuate after the central government and local authorities decided to relocate their farms to safe areas. Days later, many families were saved as the ground failed in the area destroying several houses. While actions such as this one (persuading people to relocate to a new area) could be considered extreme, they can nevertheless reduce the casualties during severe crises. Again, clear and engaging communication is fundamental for hazard and risk mitigation and should reduce unnecessary drastic actions by enabling people to respond appropriately to imminent hazards.

\subsection{Technological strategies}

Technological strategies use many of the currently available tools and platforms for remote communication. Varied internet content complementary to the official channels in the form of a social network profile [Bernard 2013b], a YouTube channel [Bernard 2017], and a blog [Bernard 2013a] are currently being used by the personnel from IG-EPN for communication and education purposes, even if it requires access to Inter- 
net and thus may not reach the same local audience as the official channels. This approach has the advantage of providing very succinct and visual information for people to learn about volcanoes and to improve communication. Since the information is not focused on news but rather on volcanology education, the audience is not polarized towards criticism of the message and its content. Thus, comments and feedback tend to be more positive than those on the official channels. This creates a "safe space" free of harsh or biased criticism that also enhances the learning process. The Facebook profile [Bernard 2013b] has accumulated 56,568 followers from 2013 to June 2021. This profile generally attracts more men (55\%) than women $(45 \%)$. Almost half of its followers (44\%) are in the 25-34 age range and $87 \%$ of them are from Ecuador. Most of the Ecuadorian followers $(63 \%)$ come from the major cities (>100,000 inhabitants) such as Quito, Guayaquil, Cuenca, Ambato, Ibarra, and Riobamba. In addition, the daily average of views from June 2020 to June 2021 is 20,957, generating 347 reactions (97\% like+love), 91 shares and 17 comments. During this period, the daily average of negative actions (unfollow/hide content) was less than 1. These metrics show a healthy level of interaction and reach for the local context.

The use of curated social media for hazard and risk communication by experts (either local or through international collaborations) is currently being implemented in other countries [Sennert et al. 2015; Syahbana et al. 2019] and increasingly a topic of discussion in volcano observatory best practices [McGuire et al. 2009; Pallister et al. 2019]. The implementation of social media involves the use of two-way communication that enriches the process and increases coherence between various members of the society, including the public, stakeholders, and scientists [Beech 2015]. A notable recent case is the modelling of an earthquakegenerated tsunami in Palu-Indonesia in 2018 by using videos from social media [Sepúlveda et al. 2020] to help explaining the tsunami's origin from the earthquake as well as associated landslides; this highlights the potential positive feedback of strengthening two-way communication on social media because it engages the community in providing scientific content necessary for understanding the hazards near them. In addition to these strategies, the use of movies, where the experiences of older generations are shared with the less experienced (and often less-engaged) younger people can be more widely spread [Hicks et al. 2017].

Based on their experiences and perspectives, the students attending the workshop presented other suggestions to improve the communication and learning processes. Considering that younger generations are more likely to learn using visual technology [Annetta 2008; Bekebrede et al. 2011], one idea discussed is the use of virtual or augmented reality to simulate different objects, environments, and hazards [Glowatz et al. 2017; Papanastasiou et al. 2018, pers. comms. from work- shop students]. As an example, the concept of scale of eruptive products and volcanoes is difficult to grasp with little or no first-hand experience. Since virtual reality can emulate various spatial dimensions [Durlach et al. 2000] and interactions [Kalawsky 1996], it can be used to educate while also being a novelty and attraction to increase attendance. The use of virtual reality representations of geological features is also logistically much easier than field trips for thousands of people, while delivering realistic ideas on the magnitude of eruptions and their impacts. Panoramic photos posted in the "Volcanes del Ecuador" Facebook profile are successful steps towards virtually visiting the volcanic sites with the addition of adding multiple dimensions to the field of view. These images have reached more than a million people and are the main attraction for the Facebook profile. In addition, IG-EPN in collaboration with the Red Cross, has used these images with virtual goggles in several events with very positive reception. A possible future use of virtual reality is to navigate through hazard maps, which the public often find difficult to understand [Thompson et al. 2015; Marti et al. 2019], especially while receiving an explanation of the possible evacuation routes or potential affected areas. Similar strategies can be implemented in a local fashion to tailor specific information and to progressively enhance communication. For example, the RIESGO demonstrator web tool [Gomez-Zapata et al. 2021] allows integration of local expert knowledge (e.g. data from IG-EPN, and provincial entities) and scenario-based models for multi-risk analysis in Latacunga (a city near Cotopaxi). This tool seeks to enhance interactive communication and understanding of hazard scenarios and intensities. An example on a different scale is currently implemented by the Instituto Geológico Minero y Metalúrgico del Perú (INGEMMET) in the form of a virtual web service for the public [INGEMMET 2019]. This user-friendly website allows people to visualize, download, and explore data of various geotechnical nature, in particular a navigable 3D map of the hazards associated with the Misti volcano.

Another activity conveyed at the workshop was the use of games to enhance and diversify the learning processes. For instance, as part of a summer course, one of the authors created a card game called Uchilla Urkukuna ("pocket volcanoes" in Quichua or kichwa, the main local indigenous language) that includes notions of geography, hazard, and exposure. The game showed very good educational outcomes in the final course evaluation when participants answered questions adequately. The workshop students also mentioned how they had assignments to create games to teach mathematics to school students, and after designing and using these games, the children showed improvements in their math skills in just a few gaming sessions. Games could be developed to recreate different eruptive scenarios for local volcanoes so that children learn and retain evacuation routes and geol- 
ogy concepts [Mani et al. 2016]. These games could be delivered to a broader audience in the form of survival, quiz, or knowledge games through free smartphone apps. Another idea is the dissemination of information through humour since people are predisposed to remember positive and happy thoughts or to learn with humorous rewards [Huang et al. 2016]. Comics, "memes," or humorous videos could be used if prepared carefully so that they are not misunderstood or underestimated [Sharpe and Izadkhah 2014].

Evacuation routes and safe sites could be automatically displayed in Google Maps and other apps, permitting easy access and dissemination of evacuation information. Just as owners can mark different business locations in Google Maps, experts and civil defence members could provide the locations of safe areas. While the successful implementation of some of these strategies still requires access to the Internet and other technological devices, they are nonetheless proven tools that accelerate, motivate, and engage the population in the learning process.

\subsection{Integrating interpersonal \& technological com- munication strategies}

While these strategies can be modified to reach different populations across the country (e.g. with the creation of mobile training groups or commercial distribution of games), one approach to combine in-person and education through technology could be the creation of the "Ecuadorian Volcano Museum". Historical and past eruptions, diverse eruptive styles, materials from across the country, and knowledge of the geodynamic processes in Ecuador, are so varied that they could be presented in a stand-alone interactive museum. This museum would include samples of volcanic deposits, photographs, testimonial videos, historical data records, scaled experimental models, and novel ideas such as virtual reality, cards, video games, etc. In the long term, a museum of this kind would attract people from across the country to visit and learn about volcanoes while reducing knowledge gaps in order to more effectively understand future hazard communications and preserve the collective memory of past eruptions. The content in the museum would also be translated to Quichua which is the language of hundreds of thousands of people in the country [Aschmann 2005] to increase reach and inclusivity. This long-term project would require a significant investment and resources, including infrastructure, new personnel, and permanent funding. However, an initial step could be the creation of a "virtual museum" that would share existing information using novel virtual reality and highly interactive displays on a single website. Steps towards a physical museum could include curation and access to real world volcanic samples or data records complementing the work already being carried out by IG-EPN and could also provide opportunities for stu- dent internships and free data access for research. Students in geosciences could volunteer to work as guides in the museum [e.g. Vulcania park, France; Vulcania 2021]. Together, these communication ideas will constitute a permanent source of visual and attractive information that will represent a beacon where new generations receive the education that they need in an accessible and timely manner. An initiative currently being enacted for a second consecutive year is the "Virtual training of Volcanic Observers (2021)" in which members of the public are encouraged to become part of a "National Volcano Observers Network" by receiving free certified training from experts of the IG-EPN [IG-EPN 2021]. The first year the training had 570 assistants from governmental institutions, academia, and the general public of which 150 were certified as volcanic observers. The volcano observers collaborate on the collection of volcanic ash at their locations with homemade ash-collectors designed by the IG-EPN, and help communicate real time observations of the nearby volcanoes through a WhatsApp group. A mobile application is being developed so that the reports are easier, more precise, and backed with evidence.

We consider that initiatives such as those described here, will prove to be valuable tools to enhance not only hazard and risk communication, but also, in a relatively short period of time, to reflect and improve on general monitoring practices.

\section{Conclusions}

In June 2019, a three-day long workshop was held in Baños, Ecuador, where scientists, students, and locals shared and discussed different experiences and aspects of volcano hazard and risk communication. The goal was to identify issues in the communication process between the official agencies (IG-EPN and SNGRE) and the people during a volcanic crisis; especially problems associated with knowledge of the sources and channels of information (Sections 2.1 and 2.2). The most prevalent communication problem identified by the workshop attendees is the lack of education and access to information on volcano hazards, which prevents the correct interpretation of messages from the official agencies. This problem can be addressed in part by increasing the engagement and presence of scientists and communication professionals with vulnerable communities. To this end, two types of strategies are proposed: 1) interpersonal training or interaction with the public and 2) self-learning through engaging on-line or physical resources such as cards or video games. Both strategies have strengths and weaknesses, for instance during interpersonal interactions it is easy to gain trust from the community but often requires difficult logistics, while on-line resources can be delivered rapidly via social media but requires access to the Internet. We suggest novel strategies that include the use of technology such as virtual reality, or smartphone apps, use 
of games and video games, and even the creation of an interactive and initially virtual or mobile "Volcano Museum". Implementation of some of these strategies by IG-EPN, such as volcanology blogs in social media, have met with great success, while others like virtual environments and simulations are plausible candidates to complement traditional communication methods. The strategies presented here aim to pave the way for people to better receive and respond to volcano (and possibly other) hazard and risk information. Initiatives like this workshop open the possibility of tackling local hazard and risk communication problems by exploring different points of views and enhancing holistic approaches. Future work should also include members of local communities and other stakeholders if allowed by logistic constraints. We recommend these as activities to be considered by other institutions in other countries.

\section{ACKNOWledgements}

The authors greatly appreciate the comments and suggestions from Kristi Wallace and other anonymous reviewers who helped improve this manuscript at different stages. The workshop was partially funded by Instituto Panamericano de Geografía e Historia (IPGH) through "Proyectos de Asistencia Técnica 2019" and by Pontificia Universidad Católica de Ecuador (PUCE) Quito through "Proyectos de Investigación PUCE 2018". The authors would like to thank the IGEPN, Universidad Yachay Tech, and Boise State University for logistical support, and Mr. Carlos Sánchez for sharing his experience and knowledge with us and for his continuous support of IG-EPN. We would also like to thank all the students from EPN, ESPE, ESPOL, Ikiam, PUCE, UEB and Yachay Tech for contributing with many of the ideas presented here. We particularly thank Francisco Romero and Ronald Estrella who helped with photography and data collection.

\section{Author contributions}

JA conceived and designed the main structure of the paper and compiled the authors' input. All authors edited, revised, and approved the final version of this manuscript.

\section{Data AVAilability}

Not applicable.

\section{Copyright NOTICE}

(C) The Author(s) 2021. This article is distributed under the terms of the Creative Commons Attribution 4.0 International License, which permits unrestricted use, distribution, and reproduction in any medium, provided you give appropriate credit to the original author(s) and the source, provide a link to the Creative
Commons license, and indicate if changes were made.

\section{REFERENCES}

Almeida, M., H. E. Gaunt, and P. Ramón (2019). "Ecuador's El Reventador Volcano Continually Remakes Itself". Eos 100. DoI: 10.1029/2019eo117105.

Andreastuti, S., A. Budianto, and E. T. Paripurno (2017). "Integrating social and physical perspectives of mitigation policy and practice in Indonesia". $\mathrm{Ob}$ serving the Volcano World. Springer, pp. 307-320.

Annetta, L. A. (2008). "Video Games in Education: Why They Should Be Used and How They Are Being Used". Theory Into Practice 47 (3), pp. 229-239. DoI: $10.1080 / 00405840802153940$.

Armijos, M. T., J. Phillips, E. Wilkinson, J. Barclay, A. Hicks, P. Palacios, P. Mothes, and J. Stone (2017). "Adapting to changes in volcanic behaviour: Formal and informal interactions for enhanced risk management at Tungurahua Volcano, Ecuador". Global Environmental Change 45, pp. 217-226. Dor: $10.1016 / j$. gloenvcha.2017.06.002.

Aschmann, R. (2005). Los idiomas quichuas del ecuador. URL: https : / / quichua . net / Q / Ec / Ecuador / E espanol.html (visited on 12/08/2021). Quichua.net.

Bablon, M., X. Quidelleur, P. Samaniego, J.-L. Le Pennec, S. Santamaría, C. Liorzou, S. Hidalgo, and B. Eschbach (2020). "Volcanic history reconstruction in northern Ecuador: insights for eruptive and erosion rates on the whole Ecuadorian arc". Bulletin of Volcanology 82 (1). DOI: 10.1007/s00445-019-1346-1.

Bachri, S., J. Stötter, M. Monreal, and J. Sartohadi (2015). "The calamity of eruptions, or an eruption of benefits? Mt. Bromo human-volcano system a case study of an open-risk perception". Natural Hazards and Earth System Sciences 15 (2), pp. 277-290. DoI: 10.5194/nhess-15-277-2015.

Beech, D. (2015). "Redesigning hazard communication through technology: collaboration, co-production and coherence". Belgeo (1). Dor: 10.4000/belgeo . 16399.

Bekebrede, G., H. J. G. Warmelink, and I. S. Mayer (2011). "Reviewing the need for gaming in education to accommodate the net generation". Computers E Education 57 (2), pp. 1521-1529. Dor: 10.1016/j . compedu.2011.02.010.

Benessia, A. and B. De Marchi (2017). "When the earth shakes ... and science with it. The management and communication of uncertainty in the L'Aquila earthquake". Futures 91, pp. 35-45. Dor: $10.1016 / \mathrm{j}$. futures.2016.11.011.

Berlo, D. K. (1960). The process of communication; an introduction to theory and practice. Tech. rep.

Bernacki, M. L. and C. Walkington (2018). "The role of situational interest in personalized learning." Journal of Educational Psychology 110 (6), pp. 864-881. DOI: $10.1037 /$ edu0000250. 
Bernard, B. (2013a). Ceniza Ecuador. URL: http : / / ceniza - ecuador . over - blog . com/ (visited on 12/08/2021).

- (2013b). Volcanes del Ecuador. (Visited on $12 / 08 / 2021)$.

- (2017). Volcanes del Ecuador. URL: https : / / wwW . youtube . com / channel / UC71PStVbhfn_UrhDz4 - ObvQ (visited on 12/08/2021).

Biass, S., C. Frischknecht, and C. Bonadonna (2012). "A fast GIS-based risk assessment for tephra fallout: the example of Cotopaxi volcano, Ecuador-Part II: vulnerability and risk assessment". Natural Hazards 64 (1), pp. 615-639. DoI: 10.1007/s11069-012-0270-x.

Bird, D. K. (2009). "The use of questionnaires for acquiring information on public perception of natural hazards and risk mitigation - a review of current knowledge and practice". Natural Hazards and Earth System Sciences 9 (4), pp. 1307-1325. DoI: 10.5194/ nhess-9-1307-2009.

Bowman, L. and P. White (2012). “'Community' perceptions of a disaster risk reduction intervention at Santa Ana (Ilamatepec) Volcano, El Salvador". Environmental Hazards 11 (2), pp. 138-154. Dor: 10.1080/ 17477891.2011 .609880$.

Bretton, R. J., J. Gottsmann, and R. Christie (2018a). "Hazard communication by volcanologists: Part 1 Framing the case for contextualisation and related quality standards in volcanic hazard assessments". Journal of Applied Volcanology 7 (1). DoI: 10.1186 / s13617-018-0077-x.

- (2018b). "Hazard communication by volcanologists: part 2 - quality standards for volcanic hazard assessments". Journal of Applied Volcanology 7 (1). DoI: 10 . 1186/s13617-018-0079-8.

Calais, E., D. Boisson, S. Symithe, C. Prépetit, B. Pierre, S. Ulyse, L. Hurbon, A. Gilles, J.-M. Théodat, T. Monfret, A. Deschamps, F. Courboulex, J. Chèze, F. Peix, E. Bertrand, J.-P. Ampuero, B. M. de Lépinay, J. Balestra, J.-L. Berenguer, R. Bossu, L. Fallou, and V. Clouard (2020). "A Socio-Seismology Experiment in Haiti". Frontiers in Earth Science 8. Dor: 10.3389/ feart. 2020.542654.

Cardona, O. D. (2004). "The need for rethinking the concepts of vulnerability and risk from a holistic perspective: a necessary review and criticism for effective risk management". Mapping vulnerability. Routledge, pp. 56-70.

Cashman, K. V. and S. J. Cronin (2008). "Welcoming a monster to the world: Myths, oral tradition, and modern societal response to volcanic disasters". Journal of Volcanology and Geothermal Research 176 (3), pp. 407-418. DoI: $10.1016 / \mathrm{j}$. jvolgeores . 2008. 01 . 040.

Chen, J. (2021). 36 essential social media marketing statistics to know for 2021. URL: https: // sproutsocial. com / insights / social - media-statistics/ (visited on $12 / 08 / 2021)$.
Christie, R., O. Cooke, and J. Gottsmann (2015). "Fearing the knock on the door: critical security studies insights into limited cooperation with disaster management regimes". Journal of Applied Volcanology 4 (1). DoI: 10.1186/s13617-015-0037-7.

Czerny, M. and A. Czerny (2020). "Urbanisation processes in zones threatened by volcanic activity: The case of Latacunga at the foot of Cotopaxi in Ecuador". Miscellanea Geographica. Regional Studies on Development 24.4, pp. 183-192.

Doyle, E. E., J. McClure, D. M. Johnston, and D. Paton (2014). "Communicating likelihoods and probabilities in forecasts of volcanic eruptions". Journal of Volcanology and Geothermal Research 272, pp. 1-15. Dor: 10.1016/j . jvolgeores.2013.12.006.

Durlach, N., G. Allen, R. Darken, R. Lee Garnett, J. Loomis, J. Templeman, and T. E. von Wiegand (2000). "Virtual Environments and the Enhancement of Spatial Behavior: Towards a Comprehensive Research Agenda". Presence: Teleoperators and Virtual Environments 9 (6), pp. 593-615. DoI: 10.1162/ 105474600300040402 .

Few, R., M. T. Armijos, and J. Barclay (2017). "Living with Volcan Tungurahua: The dynamics of vulnerability during prolonged volcanic activity". Geoforum 80, pp. 72-81. DoI: $10.1016 / \mathrm{j}$. geoforum . 2017.01 . 006.

Fischhoff, B. (2013). "The sciences of science communication". Proceedings of the National Academy of Sciences 110 (Supplement_3), pp. 14033-14039. DoI: 10. $1073 /$ pnas. 1213273110.

Gaillard, J.-C. and C. J. Dibben (2008). "Volcanic risk perception and beyond". Journal of Volcanology and Geothermal Research 172 (3-4), pp. 163-169. Dor: 10 . 1016/j. jvolgeores. 2007.12.015.

Gardner, R. G., J. S. Bednar, B. W. Stewart, J. B. Oldroyd, and J. Moore (2019). "“I must have slipped through the cracks somehow": An examination of coping with perceived impostorism and the role of social support". Journal of Vocational Behavior 115, p. 103337. DoI: $10.1016 / \mathrm{j}$. jvb.2019.103337.

Geist, D. J., A. R. McBirney, and R. A. Duncan (1986). "Geology and petrogenesis of lavas from San Cristobal Island, Galapagos Archipelago". Geological Society of America Bulletin 97 (5), p. 555. Dor: 10.1130/ $0016-7606$ (1986) $97<555$ : gapolf>2 . 0.co; 2 .

Gladfelter, S. (2018). "The politics of participation in community-based early warning systems: Building resilience or precarity through local roles in disseminating disaster information?" International Journal of Disaster Risk Reduction 30, pp. 120-131. DoI: 10 . 1016/j.ijdrr.2018.02.022.

Glowatz, M., E. Mangina, and D. Holland (2017). "Virtual, Augmented and Mixed Reality Technology Based Simulations in Higher Education". Proceedings of the 10th EAI International Conference on Simulation Tools and Techniques. ACM. Dor: 10.1145/3173519. 3173529 . 
Gomez-Zapata, J., C. Parrado, T. Frimberger, F. Barragán-Ochoa, F. Brill, K. Büche, M. Krautblatter, M. Langbein, M. Pittore, H. Rosero-Velásquez, E. Schoepfer, H. Spahn, and C. Zapata-Tapia (2021). "Community Perception and Communication of Volcanic Risk from the Cotopaxi Volcano in Latacunga, Ecuador". Sustainability 13 (4), p. 1714. Dor: 10.3390/ su13041714.

Gupta, A., H. Lamba, P. Kumaraguru, and A. Joshi (2013). "Faking Sandy". Proceedings of the 22nd International Conference on World Wide Web - WWW'13 Companion. ACM Press. DOI: 10 . 1145 / 2487788 . 2488033.

Hall, M. L. and P. A. Mothes (2008). "Volcanic impediments in the progressive development of preColumbian civilizations in the Ecuadorian Andes". Journal of Volcanology and Geothermal Research 176 (3), pp. 344-355. DoI: $10.1016 / \mathrm{j}$. jvolgeores . 2008. 01.039 .

Haynes, K., J. Barclay, and N. Pidgeon (2007). "The issue of trust and its influence on risk communication during a volcanic crisis". Bulletin of Volcanology 70 (5), pp. 605-621. DoI: 10.1007/s00445-007-0156-z.

- (2008). "Whose reality counts? Factors affecting the perception of volcanic risk". Journal of Volcanology and Geothermal Research 172 (3-4), pp. 259-272. DoI: 10.1016/j. jvolgeores. 2007.12.012.

Haynes, K., D. K. Bird, and J. Whittaker (2020). "Working outside 'the rules': Opportunities and challenges of community participation in risk reduction". International Journal of Disaster Risk Reduction 44, p. 101396. DoI: 10.1016/j.ijdrr.2019.101396.

Hickey, J., R. Lloyd, J. Biggs, D. Arnold, P. Mothes, and C. Muller (2020). "Rapid localized flank inflation and implications for potential slope instability at Tungurahua volcano, Ecuador". Earth and Planetary Science Letters 534, p. 116104. DoI: $10.1016 / \mathrm{j}$.epsl . 2020. 116104.

Hicks, A., M. T. Armijos, J. Barclay, J. Stone, R. Robertson, and G. P. Cortés (2017). "Risk communication films: Process, product and potential for improving preparedness and behaviour change". International Journal of Disaster Risk Reduction 23, pp. 138-151. Dor: 10.1016/j.ijdrr.2017.04.015.

Hicks, A., J. Barclay, J. Chilvers, M. T. Armijos, K. Oven, P. Simmons, and M. Haklay (2019). "Global Mapping of Citizen Science Projects for Disaster Risk Reduction". Frontiers in Earth Science 7. DoI: 10.3389/ feart. 2019.00226.

Hicks, A. and R. Few (2015). "Trajectories of social vulnerability during the Soufrière Hills volcanic crisis". Journal of Applied Volcanology 4 (1). DOI: 10.1186/ s13617-015-0029-7.

Hidalgo, S., J. Battaglia, S. Arellano, D. Sierra, B. Bernard, R. Parra, P. Kelly, F. Dinger, C. Barrington, and P. Samaniego (2018). "Evolution of the 2015 Cotopaxi Eruption Revealed by Combined Geochemical and Seismic Observations". Geochemistry, Geophysics,
Geosystems 19 (7), pp. 2087-2108. Dor: 10.1029 / $2018 \mathrm{gc} 007514$.

Howard, J. H. and D. V. Howard (2013). "Aging mind and brain: is implicit learning spared in healthy aging?" Frontiers in Psychology 4. Dor: 10.3389/fpsyg. 2013. 00817.

Huang, Y.-M., M.-C. Liu, C.-H. Lai, and C.-J. Liu (2016). "Using humorous images to lighten the learning experience through questioning in class". British Journal of Educational Technology 48 (3), pp. 878-896. Dor: $10.1111 /$ bjet. 12459 .

Inguaggiato, S., S. Hidalgo, B. Beate, and J. Bourquin (2010). "Geochemical and isotopic characterization of volcanic and geothermal fluids discharged from the Ecuadorian volcanic arc". Geofluids 10 (4), pp. 525-541. DoI: $10.1111 / \mathrm{j} .1468-8123.2010$. $00315 . \mathrm{x}$.

Instituto Geofísico de la Escuela Politécnica Nacional (2020a). Aclaración a la comunidad - Volcán Tungurahua. URL: https: //www.igepn. edu.ec/servicios/ noticias / 1800 - aclaracion - a - la - comunidad volcan-tungurahua (visited on 12/08/2021).

- (2020b). Servicios. URL: https: //WwW.igepn. edu.ec/ servicios (visited on 12/08/2021).

- (2021). Capacitación virtual de Observadores Volcánicos 2021. URL: https : / / docs . google. com / forms / d / e / 1FAIpQLSfuuc - DASDTXZv _ Wcq2AdlidMaqE - RvZS8dC6coq7Ku8i3txQ / viewform? fbclid = IwAR3ayNxUC7Nsh0EpB42RMSiv5hKsdVhrfjK _ fQNJIYuo-_iBm35v78P_s28 (visited on 12/08/2021).

Instituto Geológico Minero y Metalúrgico (2019). Peligros Volcánicos. URL: https : / / ingemmet - peru . maps . arcgis . com / home / group . html ? id =

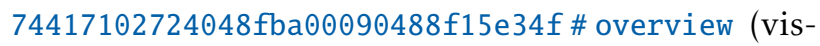
ited on 12/08/2021).

Isaacson, J. and J. Zeidler (1999). "Accidental history: volcanic activity and the end of the formative in northwestern Ecuador". Actividad volcánica y pueblos precolombinos en el Ecuador, pp. 41-72.

Jones, E. C., A. J. Faas, A. D. Murphy, G. A. Tobin, L. M. Whiteford, and C. McCarty (2013). "Cross-Cultural and Site-Based Influences on Demographic, Wellbeing, and Social Network Predictors of Risk Perception in Hazard and Disaster Settings in Ecuador and Mexico". Human Nature 24 (1), pp. 5-32. Dor: 10 . $1007 /$ s12110-013-9162-3.

Kalawsky, R. S. (1996). "Exploiting virtual reality techniques in education and training: Technological issues”. AGOCGSIMA Report Series 26 (1).

Krippner, J. (2018). “\#EruptionImminent! Wielding the double edge sword of Twitter during a volcanic crisis". AGU Fall Meeting Abstracts. Vol. 2018, PA23B05.

Lane, L. R., G. A. Tobin, and L. M. Whiteford (2003). "Volcanic hazard or economic destitution: hard choices in Banños, Ecuador". Environmental Hazards 5 (1), pp. 23-34. DoI: $10.1016 / \mathrm{j}$. hazards . 2004.01. 001. 
Le Pennec, J.-L. (2013). “A Devastating Plinian Erup tion at Tungurahua Volcano Reveals Formative Occupation at $\sim 1100$ cal BC in Central Ecuador". Radiocarbon 55 (3-4). DoI: $10.2458 /$ azu_js_rc.55.16225.

Le Pennec, J.-L., D. Jaya, P. Samaniego, P. Ramón, S. Moreno Yánez, J. Egred, and J. van der Plicht (2008). "The AD 1300-1700 eruptive periods at Tungurahua volcano, Ecuador, revealed by historical narratives, stratigraphy and radiocarbon dating". Journal of Volcanology and Geothermal Research 176 (1), pp. 70-81. DoI: $10.1016 /$ j.jvolgeores.2008.05.019.

Le Pennec, J.-L., G. A. Ruiz, P. Ramón, E. Palacios, P. Mothes, and H. Yepes (2012). "Impact of tephra falls on Andean communities: The influences of eruption size and weather conditions during the 1999-2001 activity of Tungurahua volcano, Ecuador". Journal of Volcanology and Geothermal Research 217-218, pp. 91103. DoI: $10.1016 / \mathrm{j}$. jvolgeores. 2011.06.011.

Mani, L., P. D. Cole, and I. Stewart (2016). "Using video games for volcanic hazard education and communication: an assessment of the method and preliminary results". Natural Hazards and Earth System Sciences 16 (7), pp. 1673-1689. DoI: 10.5194/nhess-16-16732016.

Martí, J. (2015). "Scientific communication of uncertainty during volcanic emergencies". Global Volcanic Hazards and Risk. Cambridge University Press, pp. 371-378. DoI: 10.1017/cbo9781316276273.026.

Marti, M., M. Stauffacher, and S. Wiemer (2019). "Difficulties in explaining complex issues with maps: evaluating seismic hazard communication - the Swiss case". Natural Hazards and Earth System Sciences 19 (12), pp. 2677-2700. DoI: $10.5194 /$ nhess-19-26772019.

McGuire, W. J., M. C. Solana, C. R. J. Kilburn, and D. Sanderson (2009). "Improving communication during volcanic crises on small, vulnerable islands". Journal of Volcanology and Geothermal Research 183 (12), pp. 63-75. Dor: $10.1016 / \mathrm{j}$. jvolgeores . 2009.02. 019.

Mei, E. T. W., F. Lavigne, A. Picquout, E. de Bélizal, D. Brunstein, D. Grancher, J. Sartohadi, N. Cholik, and C. Vidal (2013). "Lessons learned from the 2010 evacuations at Merapi volcano". Journal of Volcanology and Geothermal Research 261, pp. 348-365. DoI: 10.1016/j . jvolgeores.2013.03.010.

Mothes, P. A., M. L. Hall, D. Andrade, H. Yepes, T. C. Pierson, A. Gorki Ruiz, and P. Samaniego (2004). "Character, stratigraphy and magnitude of historical lahars of Cotopaxi volcano (Ecuador)". Character, Stratigraphy and Magnitude of Historical Lahars of Cotopaxi Volcano (Ecuador), pp. 1000-1023.

Mothes, P. A., H. A. Yepes, M. L. Hall, P. A. Ramón, A. L. Steele, and M. C. Ruiz (2015). "The scientific-community interface over the fifteen-year eruptive episode of Tungurahua Volcano, Ecuador". Journal of Applied Volcanology 4 (1). Dor: 10.1186/s13617$015-0025-\mathrm{y}$.
Nación, L. (2020). El Krakatoa habría activado el "Anillo de fuego" en el que están otros 15 volcanes. URL: https: // www . lanacion . com . ar / el - mundo / krakatoa habria - activado - anillo - fuego - estan - otros nid2353225 (visited on 12/08/2021).

Naumann, T. and D. Geist (2000). "Physical volcanology and structural development of Cerro Azul Volcano, Isabela Island, Galápagos: implications for the development of Galápagos-type shield volcanoes". Bulletin of Volcanology 61 (8), pp. 497-514. DOI: 10 . $1007 / \mathrm{s} 004450050001$.

Naumova, E. N., H. Yepes, J. K. Griffiths, F. Sempértegui, G. Khurana, J. S. Jagai, E. Játiva, and B. Estrella (2007). "Emergency room visits for respiratory conditions in children increased after Guagua Pichincha volcanic eruptions in April 2000 in Quito, Ecuador Observational Study: Time Series Analysis". Environmental Health 6 (1). DoI: 10.1186/1476-069x6-21.

Newhall, C., S. Aramaki, F. Barberi, R. Blong, M. Calvache, J.-L. Cheminee, R. Punongbayan, C. Siebe, T. Simkin, S. Sparks, and W. Tjetjep (1999). "Professional conduct of scientists during volcanic crises". Bulletin of Volcanology 60 (5), pp. 323-334. DOI: 10 . $1007 / \mathrm{pl} 00008908$.

Ortiz, H. D. (2018). "Caracterización y estadística de señales volcánicas en los Andes, casos de estudio volcanes Reventador y Cotopaxi en Ecuador". Revista Geofísica (68), pp. 119-123. DoI: 10.35424 / rgf . v७i68.938.

Ortiz, H. D., R. S. Matoza, C. Garapaty, K. Rose, P. Ramón, and M. C. Ruiz (2020). "Multi-year regional infrasound detection of Tungurahua, El Reventador, and Sangay volcanoes in Ecuador from 2006 to 2013". 179th Meeting of the Acoustical Society of America. ASA. DoI: 10.1121/2.0001362.

Ortiz, H. D., R. S. Matoza, J. B. Johnson, S. Hernandez, J. C. Anzieta, and M. C. Ruiz (2021). "Autocorrelation Infrasound Interferometry". Journal of Geophysical Research: Solid Earth 126 (4). DoI: 10.1029/ 2020jb020513.

Pallister, J., P. Papale, J. Eichelberger, C. Newhall, C. Mandeville, S. Nakada, W. Marzocchi, S. Loughlin, G. Jolly, J. Ewert, and J. Selva (2019). "Volcano observatory best practices (VOBP) workshops - a summary of findings and best-practice recommendations". Journal of Applied Volcanology 8 (1). DoI: 10.1186/s13617019-0082-8.

Papanastasiou, G., A. Drigas, C. Skianis, M. Lytras, and E. Papanastasiou (2018). "Virtual and augmented reality effects on K-12, higher and tertiary education students' twenty-first century skills". Virtual Reality 23 (4), pp. 425-436. Dor: 10.1007/s10055-018-03632.

Paton, D., M. Millar, and D. Johnston (2001). Natural Hazards 24 (2), pp. 157-169. DoI: 10.1023 / a : 1011882106373. 
Paton, D., L. Smith, M. Daly, and D. Johnston (2008). "Risk perception and volcanic hazard mitigation: Individual and social perspectives". Journal of Volcanology and Geothermal Research 172 (3-4), pp. 179-188. Dor: $10.1016 / \mathrm{j}$. jvolgeores.2007.12.026.

Primicias (2020). Un flanco del volcán Tungurahua podría "colapsar", según un estudio. URL: https : / / WWW . primicias . ec/noticias/tecnologia/volcantungurahua-podria-colapsar-segun-estudio/ (visited on $12 / 08 / 2021)$.

Robin, C., P. Samaniego, J.-L. Le Pennec, P. Mothes, and J. van der Plicht (2008). "Late Holocene phases of dome growth and Plinian activity at Guagua Pichincha volcano (Ecuador)". Journal of Volcanology and Geothermal Research 176 (1), pp. 7-15. DoI: 10.1016/ j. jvolgeores.2007.10.008.

Rubin, K. H. (2018). "Sifting Fact from Science Fiction for the Public During a Geohazard Media Event: Lessons from Kilauea Volcano in 2018". AGU Fall Meeting Abstracts. Vol. 2018, PA23B-04.

Santamaria, S. (2017). “Catálogo de eventos volcánicos ocurridos en el Ecuador continental desde el Plioceno y análisis de la frecuencia eruptiva”. PhD thesis. Escuela Politécnica Nacional.

Sennert, S. S. K., E. W. Klemetti, and D. K. Bird (2015). "Role of Social Media and Networking in Volcanic Crises and Communication". Advances in Volcanology. Springer International Publishing, pp. 733-743. DOI: 10.1007/11157_2015_13.

Sepúlveda, I., J. S. Haase, M. Carvajal, X. Xu, and P. L. F. Liu (2020). "Modeling the Sources of the 2018 Palu, Indonesia, Tsunami Using Videos From Social Media". Journal of Geophysical Research: Solid Earth 125 (3). DoI: 10.1029/2019jb018675.

Sharma, U. and A. Patt (2011). "Disaster warning response: the effects of different types of personal experience". Natural Hazards 60 (2), pp. 409-423. Dor: $10.1007 / \mathrm{s} 11069-011-0023-2$.

Sharpe, J. and Y. O. Izadkhah (2014). "Use of comic strips in teaching earthquakes to kindergarten children". Disaster Prevention and Management 23 (2), pp. 138-156. DOI: 10.1108/dpm-05-2013-0083.

Stephens, K. K., A. K. Barrett, and M. J. Mahometa (2013). "Organizational Communication in Emergencies: Using Multiple Channels and Sources to Combat Noise and Capture Attention". Human Communication Research 39 (2), pp. 230-251. Dor: 10 . 1111 /hcre. 12002.

Stern, C. R. (2004). "Active Andean volcanism: its geologic and tectonic setting". Revista geológica de Chile 31 (2). DoI: $10.4067 / \mathrm{s} 0716-02082004000200001$.

Stone, J., J. Barclay, P. Simmons, P. D. Cole, S. C. Loughlin, P. Ramón, and P. Mothes (2014). "Risk reduction through community-based monitoring: the vigías of Tungurahua, Ecuador". Journal of Applied Volcanology 3 (1). DOI: 10.1186/s13617-014-0011-9.

Syahbana, D. K., K. Kasbani, G. Suantika, O. Prambada, A. S. Andreas, U. B. Saing, S. L. Kunrat, S.
Andreastuti, M. Martanto, E. Kriswati, Y. Suparman, H. Humaida, S. Ogburn, P. J. Kelly, J. Wellik, H. M. N. Wright, J. D. Pesicek, R. Wessels, C. Kern, M. Lisowski, A. Diefenbach, M. Poland, F. Beauducel, J. Pallister, R. G. Vaughan, and J. B. Lowenstern (2019). "The 2017-19 activity at Mount Agung in Bali (Indonesia): Intense unrest, monitoring, crisis response, evacuation, and eruption". Scientific Reports 9 (1). DoI: 10.1038/s41598-019-45295-9.

Thompson, M. A., J. M. Lindsay, and J. C. Gaillard (2015). "The influence of probabilistic volcanic hazard map properties on hazard communication". Journal of Applied Volcanology 4 (1). Dor: 10.1186/s13617$015-0023-0$.

Tobin, G. A. and L. M. Whiteford (2002). "Community Resilience and Volcano Hazard: The Eruption of Tungurahua and Evacuation of the Faldas in Ecuador". Disasters 26 (1), pp. 28-48. DoI: 10.1111/1467-7717. 00189.

Vallego Vargas, S. (2011). "Distribución de las cenizas volcánicas Holocénicas - Tardías en la Costa del Ecuador". PhD thesis. Escuela Politécnica Nacional. Valverde, V., P. A. Mothes, B. Beate, and J. Bernard (2021). "Enormous and far-reaching debris avalanche deposits from Sangay volcano (Ecuador): Multidisciplinary study and modeling the $30 \mathrm{ka} \mathrm{sec-}$ tor collapse". Journal of Volcanology and Geothermal Research 411, p. 107172. DoI: $10.1016 / j$. jvolgeores . 2021.107172.

Vergauwe, J., B. Wille, M. Feys, F. De Fruyt, and F. Anseel (2014). "Fear of Being Exposed: The TraitRelatedness of the Impostor Phenomenon and its Relevance in the Work Context". Journal of Business and Psychology 30 (3), pp. 565-581. Dor: 10.1007/ s10869-014-9382-5.

Villacís, B., D. Carrillo, and A. G. Martínez (2011). "Estadística demográfica en el Ecuador: diagnóstico y propuesta". Quito: Instituto Nacional de Estadística y Censos, pp. 1-74.

Vosoughi, S., D. Roy, and S. Aral (2018). "The spread of true and false news online". Science 359 (6380), pp. 1146-1151. Dor: 10.1126/science. aap9559.

Vulcania (2021). Vulcania en Auvergne. urL: https : // WwW . vulcania.com/en/a-scientific-park/ (visited on $12 / 08 / 2021)$.

Williams, R. and J. Krippner (2019). "The use of social media in volcano science communication: challenges and opportunities". Volcanica 1 (2), pp. i-viii. Dor: 10.30909/vol.01.02.i-viii.

Yepes, H., J.-M. Nocquet, B. Bernard, P. B. Palacios, S. Vaca, and S. Aguaiza (2020). "Comments on the paper "Two independent real-time precursors of the 7.8 $\mathrm{M}$ earthquake in Ecuador based on radioactive and geodetic processes - Powerful tools for an early warning system" by Toulkeridis et al. (2019)". Journal of Geodynamics 133, p. 101648. DoI: $10.1016 / j$.jog . 2019. 101648. 